\title{
Thermal studies on the starch-g-copolymers prepared from two terpene acrylate monomers under oxidative conditions
}

\author{
Marta Worzakowska ${ }^{1}$
}

Received: 4 September 2018 / Accepted: 19 January 2019/ Published online: 22 February 2019

(C) The Author(s) 2019

\begin{abstract}
The simultaneous thermal studies (TG/DTG/DSC) coupled with the FTIR analysis of the gaseous decomposition products created under oxidative heating of starch-g-poly(neryl acrylate) and starch-g-poly(geranyl acrylate) copolymers have been presented. To these studies, the copolymers with the following grafting percents $(G)$ were selected: starch-g-poly(neryl acrylate) copolymers: $36.6 \pm 0.3 \%, 40.3 \pm 0.4 \%, 42.8 \pm 0.4 \%$ and starch-g-poly(geranyl acrylate) copolymers: $28.9 \pm 0.2 \%, 32.4 \pm 0.6 \%, 35.6 \pm 0.4 \%$. The performed tests proved that the thermal resistance of the copolymers was strongly dependent on their $G$ values, despite a small difference in the $G$ values between the samples. The slight increase (ca. 6.2-6.7\%) in the $G$ value caused the significant drop of the thermal stability of all the studied materials. The TG/DTG/ DSC studies confirmed at least three-stage decomposition mechanism of the copolymers where simultaneous pyrolysis, oxidation, dehydration and decarboxylation processes took place. The TG/FTIR analyses showed the emission of various structure fragments; among them, one can mention the creation of some organic fragments such as aldehyde, acid, alkene, alkane, furan fragments, $\mathrm{CH}_{4}$ and inorganic species $\left(\mathrm{CO}_{2}, \mathrm{CO}, \mathrm{H}_{2} \mathrm{O}\right)$ as a result of the oxidative decomposition processes of the studied copolymers. In addition, the conducted studies demonstrated similar decomposition course and mechanism for both types of the copolymers, regardless of the monomer type used to the graft process.
\end{abstract}

Keywords Potato starch $\cdot$ Starch-g-copolymers $\cdot$ Geranyl acrylate $\cdot$ Neryl acrylate $\cdot$ TG/FTIR

\section{Introduction}

The synthesis and the properties of starch graft copolymers obtained using various structure vinyl and meth(acryl) monomers have been extensively studied. Chemical modification of starch under the graft copolymerization processes allows achieving a large variety of novel, more environmentally-friendly materials with improved or modified properties than a raw starch which can be practically employed as plastics, stabilizers, compatibilizers, excipients for a drug delivery system, flocculants, heavy metal ion removal, waste water treatment, etc. Several examples which, however, do not exhaust the bibliographical references regarding the preparation of the starch

Marta Worzakowska

marta.worzakowska@poczta.umcs.lublin.pl

1 Department of Polymer Chemistry, Faculty of Chemistry, Maria Curie-Skłodowska University, Gliniana 33 Street, 20-614 Lublin, Poland graft copolymers are highlighted below. Çankaya has reported the preparation of the graft copolymers obtained from starch methacrylate and $N$-cyclohexyl acrylamide or methyl methacrylate which may be applied for fabrication of optoelectronic devices [1]. Meshram et al. [2] have described the starch graft copolymers synthesized from the mixture of monomers such as styrene/methyl methacrylate or styrene/butyl acrylate suitable textiles application. Several authors have presented the synthesis and the properties of starch-g-polyacrylonitrile copolymers [3-9]. The studies on the starch-g-poly(methyl methacrylate) are widely described [10-15]. Also, the properties of starch-g-poly(vinyl acetate) are presented [16-19]. Starch/lactic acid graft copolymers [20-22], maleated thermoplastic starch-gpolylactic acid [23], esterified maleic anhydride starch-gpolylactic acid [24], hydroxyethyl starch-grafted-polylactide [25], starch-g-poly(vinyl alcohol) [26], starch-gpoly $(n$-vinylimidazole) [27], carboxymethyl starch-gpoly $(N$-vinylimidazole) [28, 29] copolymers have been precisely studied. In addition, the copolymers received 
from potato starch and aromatic type meth(acrylate) monomers [30-36] and more, environmentally-friendly starch-g-poly(citronellyl acrylate) [37] and starch-gpoly(citronellyl methacrylate) copolymers [38, 39] under the free radical copolymerization have been presented.

One of the most important properties of any new, received materials are the thermal stability because it determines the application of the novel materials in the appropriate section of an industry. Generally, the thermal stability and the decomposition course of various origins materials are tested by the thermogravimetric analysis. This method permits the evaluation of initial decomposition temperatures, the maximum decomposition temperatures, the mass losses in each decomposition stage, residual mass, the amount of the residue, etc. It is a simple and fast method in order to verify the thermal properties of the studied compounds. This method is often connected with the spectroscopic methods which make it possible to specify the type of the volatiles emitted under decomposition of the heated compounds and thus their potential decomposition mechanism [40-47].

The present paper describes the oxidative thermal properties and the decomposition course of starch-gcopolymers prepared from two terpene acrylate monomers obtained from two geometric isomers of terpene alcohol: cis-3,7-dimethyl-2,6-octadien-1-ol (nerol) and trans-3,7dimethyl-2,6-octadien-1-ol (geraniol) which are evaluated using the TG/DTG/DSC/FTIR-coupled method. The effect of the grafting percent and the structure of the copolymers on their thermal resistance, decomposition course and decomposition mechanism was specified.

\section{Experimental}

\section{Materials}

Starch-g-copolymers were prepared from potato starch and two terpene acrylate monomers under the graft copolymerization process applying the "grafting from" method. Terpene acrylate monomers were obtained from two geometric isomers of naturally occurring terpene alcohol: geraniol and nerol according to the method described in Refs. [33, 34, 38]. Potato starch (purity 97\%) was extracted and purified from potato flour produced by Melvit S.A., Poland, according to the procedure described elsewhere [48]. It was composed of amylopectin (83\%) and amylose $(17 \%)$ which was determined by the technique described in Ref. [49]. To the thermal studies, the materials prepared during the listed below graft reaction conditions were selected, Table 1. Their structures were affirmed by the spectroscopic methods.
Table 1 The grafting percent $(\% G)$ and grafting efficiency (\%GE) of the selected materials

\begin{tabular}{lll}
\hline Copolymer no/starch to monomer ratios & GE/\% & G/\% \\
\hline Geranyl acrylate & & \\
Copolymer 1/1:0.25 & $72.5 \pm 0.6$ & $28.9 \pm 0.2$ \\
Copolymer 2/1:0.75 & $76.9 \pm 0.7$ & $32.4 \pm 0.6$ \\
Copolymer 3/1:1 & $79.0 \pm 0.6$ & $35.6 \pm 0.4$ \\
Neryl acrylate & & \\
Copolymer 4/1:0.25 & $94.4 \pm 0.8$ & $36.6 \pm 0.3$ \\
Copolymer 5/1:1 & $90.2 \pm 0.6$ & $40.3 \pm 0.4$ \\
Copolymer 6/1:1.5 & $90.7 \pm 0.8$ & $42.8 \pm 0.4$ \\
\hline
\end{tabular}

The graft reaction conditions: starch-g-poly(geranyl acrylate) copolymers: the reaction temperature of $70{ }^{\circ} \mathrm{C}$, the reaction time of $210 \mathrm{~min}$, initiator (potassium persulfate) concentration of 2.5 mass $\%$, rmp 300

Starch-g-poly(neryl acrylate) copolymers: the reaction temperature of $70{ }^{\circ} \mathrm{C}$, the reaction time of $180 \mathrm{~min}$, initiator (potassium persulfate) concentration of 2.0 mass $\%, \mathrm{rmp} 300$

Starch-g-poly(geranyl acrylate) copolymers: FTIR (KBr disk, $\left.\mathrm{cm}^{-1}\right): 3315(v \mathrm{OH}), 3010(v=\mathrm{C}-\mathrm{H}), 2950(v \mathrm{C}-\mathrm{H})$, 2915 ( $v$ C-H $), 2845$ ( $v$ C-H $), 1730$ ( $v$ C $=\mathrm{O}), 1630$ (moisture), $1437(\delta \mathrm{C}-\mathrm{H}), 1375(\delta \mathrm{C}-\mathrm{H}), 1147(v \mathrm{C}-\mathrm{O})$, $1051(v \mathrm{C}-\mathrm{O}), 1008$ ( $v \mathrm{C}-\mathrm{O}), 925(v \mathrm{C}-\mathrm{O}), 835(\gamma=\mathrm{CH})$, $760(\gamma=\mathrm{CH}) ;{ }^{13} \mathrm{C} \mathrm{CP} / \mathrm{MAS}$ NMR $(75 \mathrm{MHz}, \delta \mathrm{ppm}): 174.1$ $(\mathrm{C}=\mathrm{O}), 141.5(=\mathrm{C}), 135.7(=\mathrm{C}), 122.5(=\mathrm{CH}), 117.5(=\mathrm{CH})$, $100.7(\mathrm{CH}-\mathrm{O}), 93.8(\mathrm{CH}-\mathrm{O}), 80.2(\mathrm{CH}-\mathrm{O}), 72.3(\mathrm{C}-\mathrm{O})$, $61.1\left(\mathrm{CH}_{2}-\mathrm{O}\right), 38.3-28.7\left(\mathrm{CH}_{2}\right), 25.2\left(\mathrm{CH}_{3}\right), 23.6\left(\mathrm{C}-\mathrm{CH}_{2}\right)$, $17.7\left(\mathrm{CH}_{3}\right)$.

Starch-g-poly(neryl acrylate) copolymers: FTIR ( $\mathrm{KBr}$ disk, $\left.\mathrm{cm}^{-1}\right)$ : $3310(v \mathrm{OH}), 3010(v=\mathrm{C}-\mathrm{H}), 2947(v \mathrm{C}-\mathrm{H})$, 2912 ( $v$ C-H $), 2846$ ( $v$ C-H), 1729 ( $v \quad \mathrm{C}=\mathrm{O}), 1630$ (moisture), $1435(\delta \mathrm{C}-\mathrm{H}), 1371(\delta \mathrm{C}-\mathrm{H}), 1147(v \mathrm{C}-\mathrm{O})$, 1053 ( $v \mathrm{C}-\mathrm{O}), 1008$ ( $v \mathrm{C}-\mathrm{O}), 924(v \mathrm{C}-\mathrm{O}), 835(\gamma=\mathrm{CH})$, $758(\gamma=\mathrm{CH}) ;{ }^{13} \mathrm{C} \mathrm{CP} / \mathrm{MAS}$ NMR $(75 \mathrm{MHz}, \delta \mathrm{ppm}): 174.3$ $(\mathrm{C}=\mathrm{O}), 141.6(=\mathrm{C}), 135.9(=\mathrm{C}), 122.6(=\mathrm{CH}), 117.2(=\mathrm{CH})$, $100.6(\mathrm{CH}-\mathrm{O}), 93.8(\mathrm{CH}-\mathrm{O}), 80.5(\mathrm{CH}-\mathrm{O}), 72.4(\mathrm{C}-\mathrm{O})$, $61.2\left(\mathrm{CH}_{2}-\mathrm{O}\right), 38.4-28.6\left(\mathrm{CH}_{2}\right), 25.3\left(\mathrm{CH}_{3}\right), 23.5(\mathrm{C}-$ $\left.\mathrm{CH}_{2}\right), 17.6\left(\mathrm{CH}_{3}\right)$.

\section{Methods}

The FTIR spectra of the prepared materials in the wavenumber region from 600 to $4000 \mathrm{~cm}^{-1}$ and $4 \mathrm{~cm}^{-1}$ resolution using $\mathrm{KBr}$ disk technique and the absorption mode on a FTIR Tensor 27, Bruker spectrometer, were gathered.

The ${ }^{13} \mathrm{C}$ CP/MAS NMR spectra of the copolymers at the resonance frequency of $75.5 \mathrm{MHz}$ on a Bruker Avance 300 MSL apparatus were collected. 
The thermal studies (TG-DTG-DSC) of the obtained starch-g-copolymers on a STA 449 Jupiter F1 Netzsch (Germany) apparatus have been made. The analyses in open $\mathrm{Al}_{2} \mathrm{O}_{3}$ crucibles using sample mass ca. $10 \mathrm{mg}$ under synthetic air atmosphere (flow rate $100 \mathrm{~mL} \mathrm{~min}{ }^{-1}$ ) and at temperatures between 40 and $700{ }^{\circ} \mathrm{C}$ have been performed. The heating rate was $10{ }^{\circ} \mathrm{C} \mathrm{min}^{-1}$. Each experiment was repeated three times. The TG-DSC instrument was calibrated with standard weights according to the manufacturer proceedings (temperature and sensitivity calibrations) and checked with calcium oxalate monohydrate. The Netzsch Proteus Thermal Analysis (version 5.2.) software was used to analyze the data.

The identification of the type of gaseous products emitted under the heating of the copolymers by a FTIR spectrometer Bruker TGA 585 (Germany) coupled with a STA instrument has been made. The FTIR spectra for the volatiles at the wave range of $600-4000 \mathrm{~cm}^{-1}$ and $4 \mathrm{~cm}^{-1}$ resolution were gathered.

\section{Results and discussion}

The course of the TG/DTG/DSC curves is presented in Figs. 1 and 2. However, the data read from the thermal curves are placed in Table 2. As it is well seen, similar course of the thermal curves for both types of starch-gcopolymers is observed. Generally, on the TG/DTG curves, four ranges of the mass loss are clearly indicated. First range of the mass loss with a mass loss below $8 \%$, from $40{ }^{\circ} \mathrm{C}$ to ca. $150{ }^{\circ} \mathrm{C}$ with $T_{\max 0}$ from 77 to $110{ }^{\circ} \mathrm{C}$ is appeared. On the DSC curves, only one endothermic signal is visible at this temperature range. This low-temperature signal as it is confirmed based on the gaseous FTIR spectra, as shown in Figs. 3 and 4, is due to the evaporation of the moisture from the studied materials. On the gaseous FTIR spectra, only the absorption bands characteristic for water vapor at the range of $1400-1800 \mathrm{~cm}^{-1}$ and $3500-3900 \mathrm{~cm}^{-1}$ are observed.

The heating of the copolymers above $200{ }^{\circ} \mathrm{C}$ in oxidative conditions causes their decomposition. For all the studied materials, the first decomposition stage composed of at least two steps at the temperature range between ca. $200{ }^{\circ} \mathrm{C}$ and ca. $420{ }^{\circ} \mathrm{C}$ and with $T_{\max 1}$ from 277 to $283{ }^{\circ} \mathrm{C}$ is detected. The mass loss in this stage is comparable for all the studied materials and amounts from 62.2 to $66.3 \%$. Moreover, as the $\% G$ increases, the copolymers are characterized by a less thermal stability as it is confirmed by their initial decomposition temperatures marked as $5 \%$ of the mass loss (IDT). For starch-g-poly(geranyl acrylate) copolymers, the initial decomposition temperatures for growing the $\% G$ are as follows: $266{ }^{\circ} \mathrm{C}, 250{ }^{\circ} \mathrm{C}$ and $231^{\circ} \mathrm{C}$. However, for starch-g-poly(neryl acrylate)
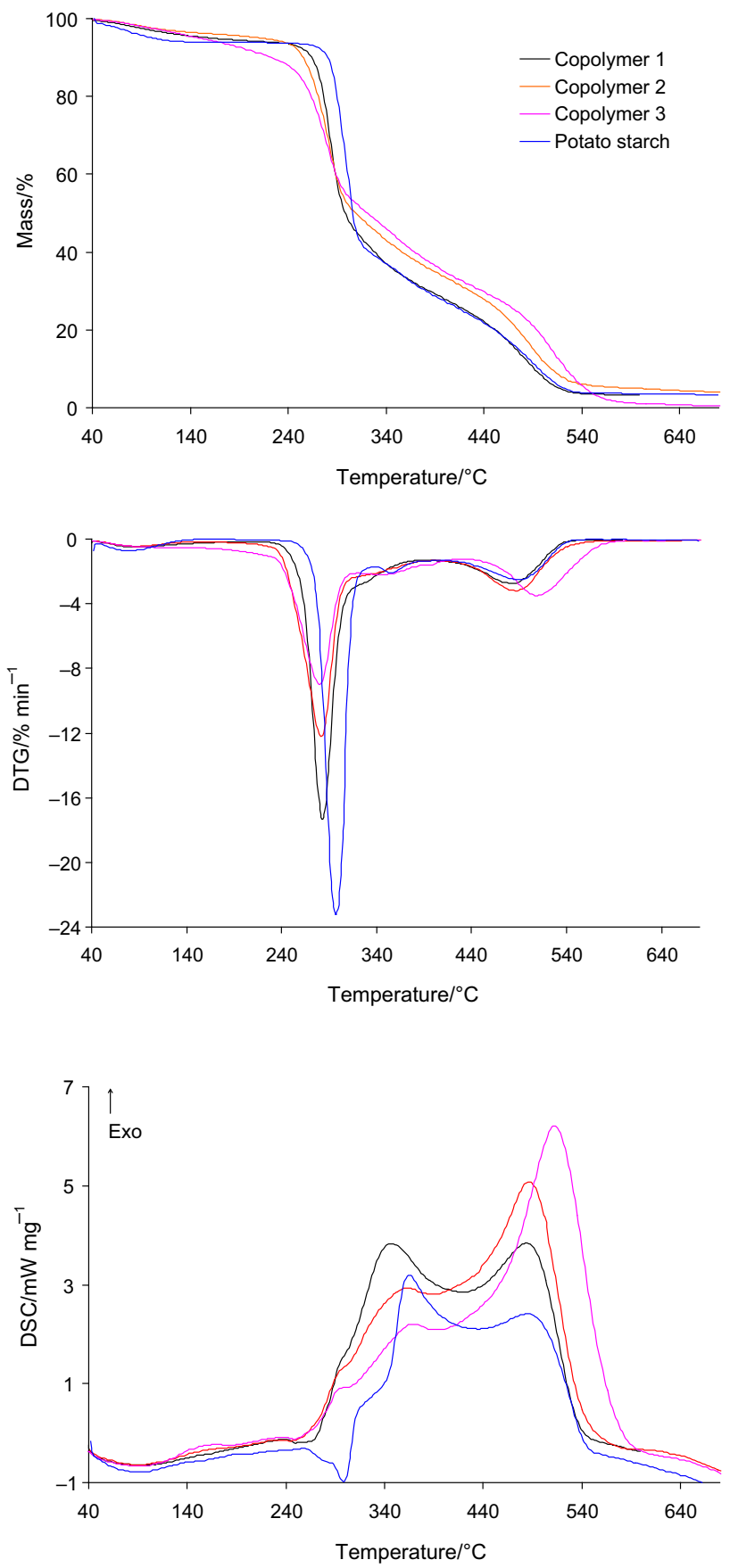

Fig. 1 TG/DTG/DSC curves for starch-g-poly(geranyl acrylate) copolymers

copolymers, the corresponding IDT values are $256^{\circ} \mathrm{C}$, $248{ }^{\circ} \mathrm{C}$ and $210{ }^{\circ} \mathrm{C}$, respectively. The differences in the $\% G$ are not dramatically high, but there are influenced considerably on the thermal resistance of the obtained materials. As it is visible, enhancement the $\% G$ values only ca. $6 \%$ causes the significant drop of IDT values. In the case of starch-g-poly(geranyl acrylate), the IDT values are ca. $35{ }^{\circ} \mathrm{C}$ lower for the $\% G$ which amounts to ca. $35.6 \%$ than those observed for the $\% G$ ca. $28.9 \%$. On the contrary, 

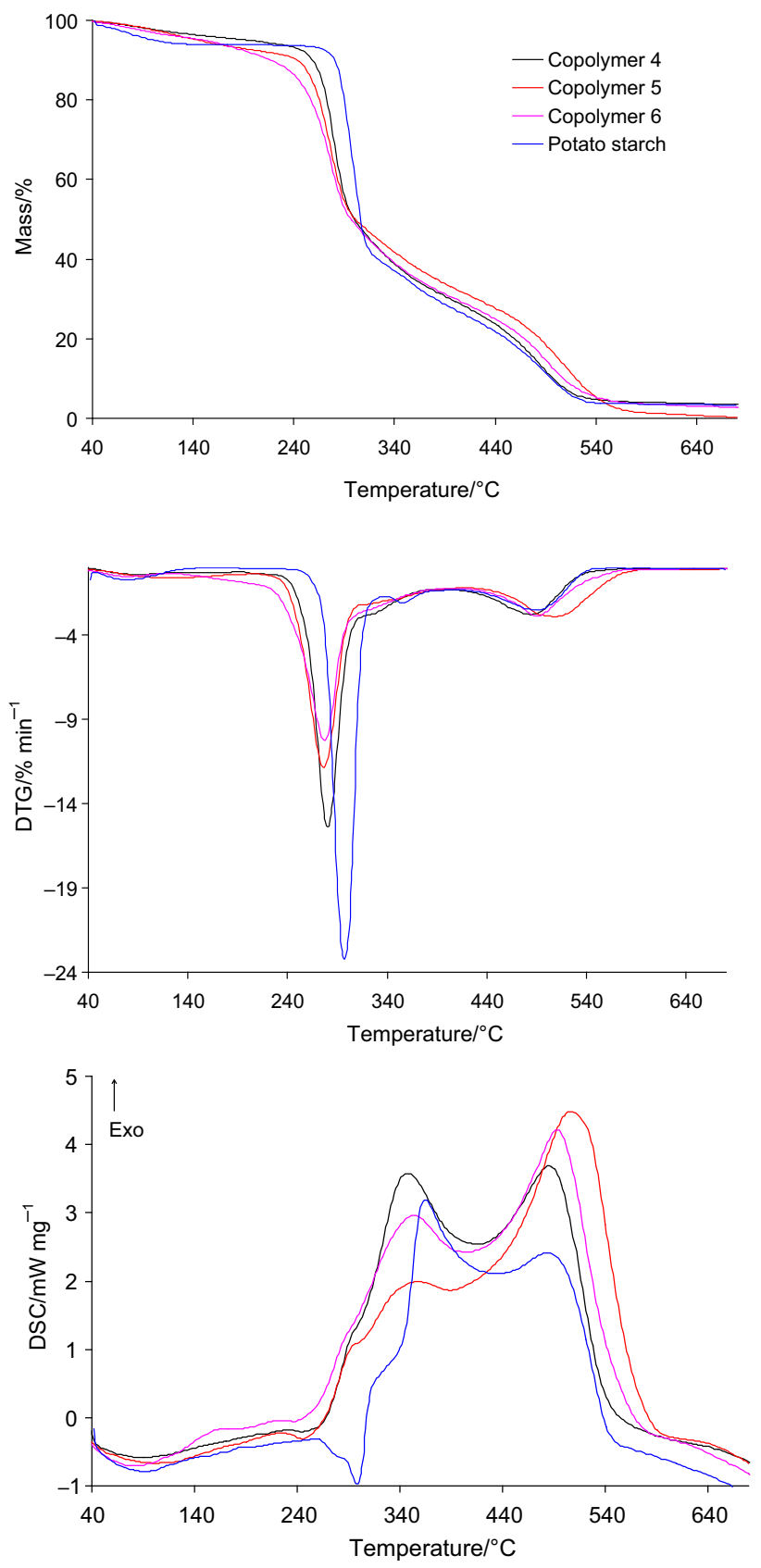

Fig. 2 TG/DTG/DSC curves for starch-g-poly(neryl acrylate) copolymers

the IDT values are ca. $46{ }^{\circ} \mathrm{C}$ lower for starch-g-poly(neryl acrylate) copolymers with the $\% G$ which equals ca. $42 \%$ than those for the $\% G$ amounting to ca. 36.6\%. Moreover, taking into account the values of the IDT, one can see that copolymers prepared from trans terpene acrylate isomer are characterized by higher thermal stability than those obtained from cis terpene acrylate isomer. It may be due to higher energy needed in order to decompose the bonds in the structure of the copolymers obtained from trans monomer as compared to the energy required to break the bonds in the structure of the copolymers prepared from $c i s$ monomer. Moreover, the IDT values for the copolymers are lower as compared to these values obtained for unmodified potato starch (ca. $280{ }^{\circ} \mathrm{C}$ ). This can be because of higher energy is needed in order to break the glycosidic bonds in starch macromolecule than the bonds in the copolymer structure. What is interesting is that depending on the $\% G$ values, the differences in the rate of the decomposition of the copolymers are shown. The rate of the decomposition increases as the $\% G$ values of the copolymers decrease, as shown in Figs. 1 and 2. It means that the copolymers with lower $\% G$ values and unmodified potato starch decompose faster than these copolymers characterized by higher $\% G$ values. As it is well seen, the DSC curves show only exothermic signals at this temperature range. It may be the evidence of some chemical processes of the volatiles and residues with oxygen which lead to obtain different structure gaseous fragments. According to the gaseous FTIR spectra collected at $T_{\max 1}$, the emission of some organic fragments such as aldehyde, acid, alkene, alkane and furan fragments as a result of the oxidative decomposition of the copolymers is confirmed, as shown in Figs. 3 and 4. On the FTIR spectra, one can notice the absorption bands characteristic for the following vibrations: the stretching vibrations of $\mathrm{OH}$ (above $3500 \mathrm{~cm}^{-1}$ ), the stretching vibrations of $=\mathrm{C}-\mathrm{H}$ and $\mathrm{C}_{\mathrm{Ar}-\mathrm{H}}$ $\left(3072 \mathrm{~cm}^{-1}\right)$, the stretching vibrations of $\mathrm{C}-\mathrm{H}$ $\left(2720-2990 \mathrm{~cm}^{-1}\right)$, the stretching vibrations of $\mathrm{C}=\mathrm{O}$ $\left(1722-1790 \mathrm{~cm}^{-1}\right)$, the stretching vibrations of $\mathrm{C}=\mathrm{C}$ (1656-1660 $\left.\mathrm{cm}^{-1}\right)$, the stretching vibrations of $\mathrm{C}=\mathrm{C}_{\mathrm{Ar}}$ $\left(1500 \mathrm{~cm}^{-1}\right.$ and $\left.1565 \mathrm{~cm}^{-1}\right)$, the deformation vibrations of $\mathrm{C}-\mathrm{H}\left(1350-1450 \mathrm{~cm}^{-1}\right)$, the stretching vibrations of $\mathrm{C}-\mathrm{O}$ $\left(1074-1220 \mathrm{~cm}^{-1}\right)$, the out-of-plane deformation vibrations of $=\mathrm{C}-\mathrm{H}$ and $\mathrm{C}_{\mathrm{Ar}-\mathrm{H}}\left(720-982 \mathrm{~cm}^{-1}\right)$. In addition to the above vibrations, the emission of $\mathrm{CO}, \mathrm{CO}_{2}$ and $\mathrm{H}_{2} \mathrm{O}$ is confirmed based on the presence of their characteristic bands.

However, the gaseous FTIR spectra gathered at the temperature (ca. $340{ }^{\circ} \mathrm{C}$ ), where a small shoulder on the DTG curves is noticed, indicate on the emission of different structure volatile fragments than those created at $T_{\max 1}$. One can see the following characteristic absorption bands at wavelengths of approx. $2720 \mathrm{~cm}^{-1}$ (the stretching vibrations of $\mathrm{C}-\mathrm{H}$ in aldehyde groups), $2777-2952 \mathrm{~cm}^{-1}$ (the stretching vibrations of $\mathrm{C}-\mathrm{H}$ ), three non-well separated bands at $1695 \mathrm{~cm}^{-1}, 1756 \mathrm{~cm}^{-1}$ and $1790 \mathrm{~cm}^{-1}$ (the stretching vibrations of $\mathrm{C}=\mathrm{O}$ ), $1357 \mathrm{~cm}^{-1}$ (the deformation vibrations of $\mathrm{C}-\mathrm{H}$ ), $1072-1170 \mathrm{~cm}^{-1}$ (the stretching vibrations of $\mathrm{C}-\mathrm{O}$ ), and $809-983 \mathrm{~cm}^{-1}$ (the out-of-plane deformation vibrations of $=\mathrm{C}-\mathrm{H}$ ). It indicates on the emission of aldehyde, alkane and alkene fragments under oxidative conditions as a result of the decomposition processes of poly(geranyl acrylate) and poly(neryl acrylate) 
Table 2 The data received from the thermal curves

\begin{tabular}{lcllllll}
\hline Sample & $T_{\max 0} /{ }^{\circ} \mathrm{C}$ & $\Delta_{\mathrm{m} 0} / \%$ & $T_{\max 1} /{ }^{\circ} \mathrm{C}$ & $\Delta_{\mathrm{m} 1} / \%$ & $T_{\max 2} /{ }^{\circ} \mathrm{C}$ & $\Delta_{\mathrm{m} 2} / \%$ & $\mathrm{rm} / \%$ \\
\hline Copolymer 1 & 92 & 5.8 & 283 & 65.2 & 483 & 25.7 & 3.3 \\
Copolymer 2 & 88 & 4.3 & 282 & 62.4 & 487 & 28.5 & 4.8 \\
Copolymer 3 & 94 & 6.0 & 280 & 62.8 & 509 & 30.1 & 1.1 \\
Copolymer 4 & 91 & 4.8 & 280 & 65.1 & 484 & 26.0 & 4.1 \\
Copolymer 5 & 110 & 7.5 & 277 & 62.2 & 508 & 29.1 & 1.2 \\
Copolymer 6 & 77 & 4.0 & 278 & 66.3 & 490 & 26.2 & 3.5 \\
Potato starch & 79 & 6.1 & $297 / 356$ & 67.1 & 492 & 23.3 & 3.5 \\
\hline
\end{tabular}

$r m$ residual mass at $640{ }^{\circ} \mathrm{C}$ (a)
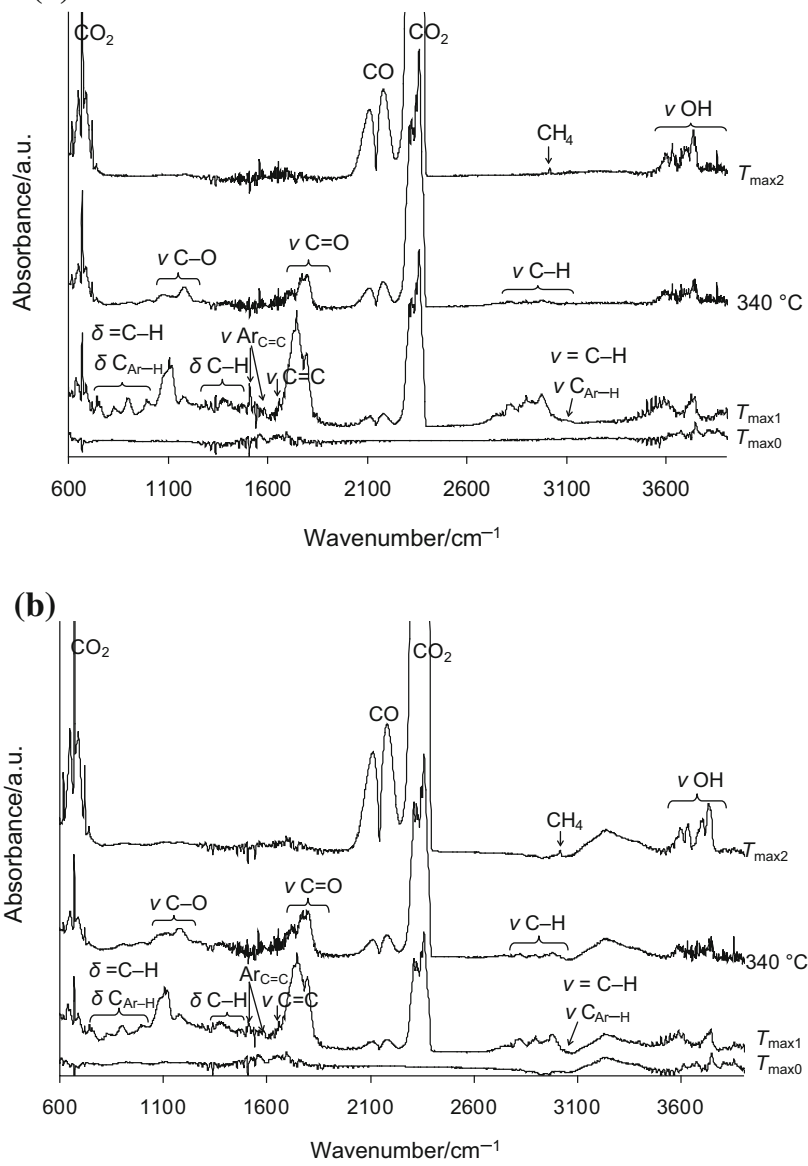

Fig. 3 The gaseous FTIR spectra collected under oxidative decomposition of starch-g-poly(geranyl acrylate) copolymers: a copolymer 1 , b copolymer 3

chains. In addition, a high emission of $\mathrm{CO}_{2}$ (the bands at $670 \mathrm{~cm}^{-1}$ and at $2330-2365 \mathrm{~cm}^{-1}$ ), $\mathrm{CO}$ (the bands at 2000-2200 $\mathrm{cm}^{-1}$ ) and $\mathrm{H}_{2} \mathrm{O}$ (the bands above $3500 \mathrm{~cm}^{-1}$ ) confirms the oxidation and decarboxylation processes of the intermediate decomposition gaseous fragments, as shown in Figs. 3 and 4.

The second decomposition stage spreads from the temperature ca. $400-$ ca. $610^{\circ} \mathrm{C}$. This decomposition stage is

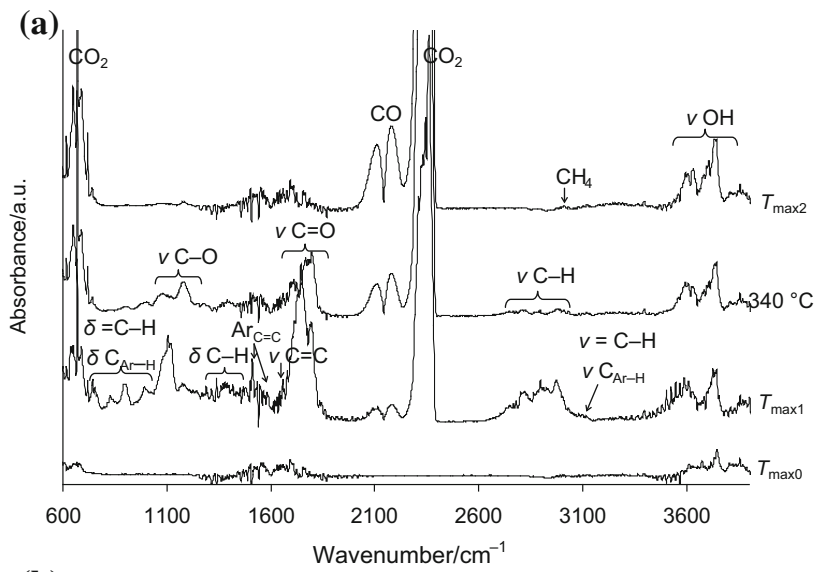

(b)

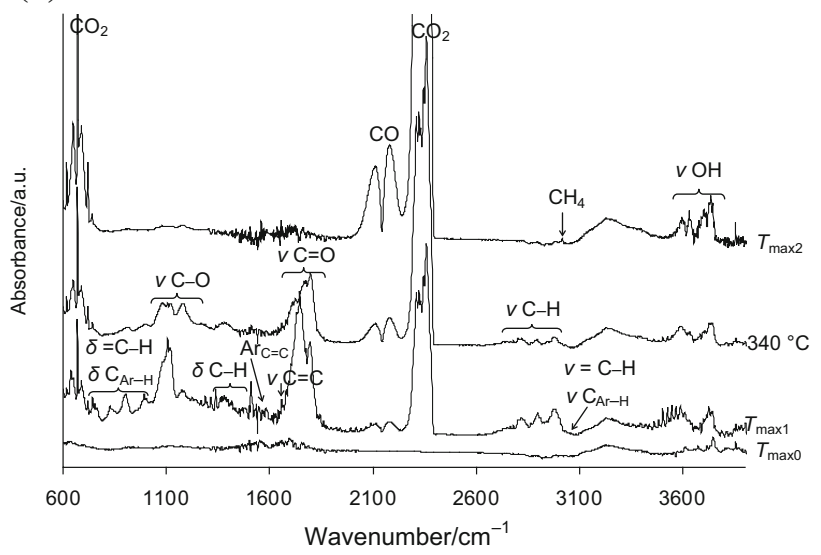

Fig. 4 The gaseous FTIR spectra collected under oxidative decomposition of starch-g-poly(neryl acrylate) copolymers: a copolymer 4 , b copolymer 6

described by one, symmetrical DTG signal which happens at $T_{\max 2} 483-509{ }^{\circ} \mathrm{C}$. The position of this signal depends on the copolymer type and its $\% G$. The mass loss in this stage is comparable for all the studied materials and hesitates from 25.7 to $30.1 \%$. If one have a look at the DSC curves, one can see only exothermic signals within this decomposition stage. It could be an indication on further reactions of the volatile fragments and/or residues with oxygen at higher temperatures. It causes almost full decomposition of the studied materials; only minor amount 
of carbon residues is indicated (1.1-4.8\%). As main gaseous products $\mathrm{CO}_{2}, \mathrm{CO}$ and $\mathrm{H}_{2} \mathrm{O}$ are created as it is confirmed from the gaseous FTIR spectra. The results indicate on a complex decomposition mechanism of the studied materials and prove that regardless of the type of monomer (cis or trans), the decomposition course and decomposition mechanism are similar.

\section{Conclusions}

In this paper, the studies on the thermal oxidative resistance and oxidative decomposition mechanism of two types of the copolymers prepared under the graft reaction of potato starch and monomers synthesized from two geometric isomers of naturally occurring terpene alcohols (nerol-cis isomer and geraniol-trans isomer) and methacryloyl chloride have been presented. The thermal properties have been determined using the TG/DTG/DSC method. The oxidative decomposition mechanism has been evaluated involving the TG/FTIR-coupled method. The copolymers with the following grafting percent values $(G)$ were selected to the above experiments: starch-gpoly(neryl acrylate) copolymers $36.6 \pm 0.3 \%$, $40.3 \pm 0.4 \%, \quad 42.8 \pm 0.4 \%$ and starch-g-poly(geranyl acrylate) copolymers: $28.9 \pm 0.2 \%, \quad 32.4 \pm 0.6 \%$, $35.6 \pm 0.4 \%$, respectively. The conducted tests led to the following observations and results:

- The differences in the $G$ values between the samples were little; however, the growth of the $G$ values caused the substantial fall of the oxidative thermal stability of the copolymers. The thermal stability for starch-gpoly(neryl acrylate) copolymers decreased by $46{ }^{\circ} \mathrm{C}$ for the copolymer with the $G$ value equal to $42.8 \pm 0.4 \%$ as compared with the thermal stability of the copolymer with the $G$ value equal to $36.6 \pm 0.3 \%$. Meanwhile, the oxidative thermal resistance for starch-g-poly(geranyl acrylate) copolymer with the $G$ equal to $35.6 \pm 0.4 \%$ was ca. $35^{\circ} \mathrm{C}$ lower than this observed for the copolymer with the $G$ equal to $28.9 \pm 0.2 \%$;

- Generally, all the studied copolymers decomposed at least three stages under oxidative conditions;

- The first decomposition stage composed of at least two steps happened between ca. 200 and ca. $420{ }^{\circ} \mathrm{C}$. The mass loss in this stage was significant (62.2-66.3\%), and it was connected with the emission of aldehyde, acid, alkene, alkane, furan fragments, $\mathrm{CO}_{2}, \mathrm{CO}$, and $\mathrm{H}_{2} \mathrm{O}$ as a results of the simultaneous pyrolysis, oxidation, dehydration and decarboxylation processes of potato starch, poly(neryl acrylate) and poly(geranyl acrylate) chains;
- The second decomposition stage was observed at the temperature range of ca. $400-\mathrm{ca} .610^{\circ} \mathrm{C}$ and the mass loss from 25.7 to $30.1 \%$. Mainly, the creation of inorganic species such as $\mathrm{CO}_{2}, \mathrm{CO}, \mathrm{H}_{2} \mathrm{O}$ and very small amounts of $\mathrm{CH}_{4}$ was emitted which was due to the oxidation processes of the formed volatiles and residues.

It is therefore concluded that starch-g-poly(neryl acrylate) copolymers were less thermally stable materials under the heating in the presence of air atmosphere than starch-gpoly(geranyl acrylate) copolymers. However, their thermal decomposition course and decomposition mechanism were almost similar.

Open Access This article is distributed under the terms of the Creative Commons Attribution 4.0 International License (http://creative commons.org/licenses/by/4.0/), which permits unrestricted use, distribution, and reproduction in any medium, provided you give appropriate credit to the original author(s) and the source, provide a link to the Creative Commons license, and indicate if changes were made.

\section{References}

1. Çankaya N. Synthesis of graft copolymers onto starch and its semiconducting properties. Res Phys. 2016;6:538-42.

2. Meshram MW, Patil VV, Mhaske ST, Thorat BN. Graft copolymers of starch and its application in textiles. Carbohydr Polym. 2009;75:71-8.

3. Fanta GF, Burr RC, Russell CR, Rist CE. Graft copolymers of starch. I. Copolymerization of gelatinized wheat starch with acrylonitrile. Fractionation of copolymer and effect of solvent on copolymer composition. J Appl Polym Sci. 1966;10:929-37.

4. Saroja N, Shamala TR, Tharanathan RN. Biodegradation of starch-g-polyacrylonitrile, a packaging material, by Bacillus cereus. Process Biochem. 2000;36:119-25.

5. Gosavia UR, Deopurkarb RL, Gholea VS. Saponified starch-gpolyacrylonitrile gels as carbon source in bacterial culturing. Polymer. 1998;39:3859-62.

6. Weaver MO, Gugliemelli LA, Doane WM, Russell CR. Hydrolyzed starch-polyacrylonitrile graft copolymers: effect of structure on properties. J Appl Polym Sci. 1971;15:3015-24.

7. Fanta GF, Burr RC, Doane WM. Factors influencing absorbent properties of saponified starch-g-polyacrylonitrile isolated by methanol precipitation. Starch Starke. 1984;36:416-9.

8. Castel D, Ricard A, Audebert R. Preparation of starch graft copolymers: Influence of several parameters on structure and properties. J Macromol Sci Part A Chem. 1988;25:235-46.

9. Lim DW, Whang HS, Yoon KJ, Ko SW. Synthesis and absorbency of a superabsorbent from sodium starch sulfate-g-polyacrylonitrile. J Appl Polym Sci. 2001;79:1423-30.

10. Cho CG, Lee K. Preparation of starch-g-PMMA copolymer by emulsion polymerization. Carbohydr Polym. 2002;48:125-30.

11. Pimpan V, Thothong P. Synthesis of cassava starch-g-poly(methyl methacrylate) copolymers with benzoyl peroxide as an initiator. J Appl Polym Sci. 2006;101:4083-9.

12. Misra BM, Dogra R. Grafting onto starch. IV. Graft copolymerization of methyl methacrylate by use of AIBN as radical initiator. J Macromol Sci Part A Chem. 1980;14:763-70. 
13. Wang L, Shen J, Men Y, Wu Y, Peng Q, Wang X, Yang R, Mahmood K, Liu Z. Corn starch-based graft copolymers prepared via ATRP at the molecular level. Polym Chem. 2015;18:3480-8.

14. Li MC, Ge X, Cho UR. Emulsion grafting vinyl monomers onto starch for reinforcement of styrene-butadiene rubber. Macromol Res. 2013;21:519-28.

15. Zhang QL, Tian XH, Sun JY, Yuan YZ, Zhang KT. Preparation of starch-g-PMMA, starch-g-P(MMA/BMA) and starch-g$\mathrm{P}(\mathrm{MMA} / \mathrm{MA})$ nanoparticles and their reinforcing effect on natural rubber by latex blending: a comparative study. Polym Sci Ser A. 2017;59:708-17.

16. Samaha SH, Nasr HE, Hebeish A. Synthesis and characterization of starch-poly(vinyl acetate) graft copolymers and their saponified form. J Polym Res. 2005;12:343-53.

17. Fanta GF, Burr RC, Doane WM, Russell CR. Graft polymerization of vinyl acetate onto starch. Saponification to starch-gpoly(vinyl alcohol). J Appl Polym Sci. 1979;23:229-40.

18. Nie Y, Tian X, Liu Y, Wu K, Wang J. Research on starch-gpolyvinyl acetate and epoxy resin-modified corn starch adhesive. Polym Compos. 2013;34:77-87.

19. Niu Y, Li H. Controlled release of urea encapsulated by starch-gpoly(vinyl acetate). Ind Eng Chem Res. 2012;51:12173-7.

20. Hu Y, Wang Q, Tang M. Preparation and properties of starch-gPLA/poly(vinyl alcohol) composite film. Carbohydr Polym. 2013;96:384-8

21. Tudorachi N, Lipsa R, Mustata FR. Thermal degradation of carboxymethyl starch-g-poly(lactic acid) copolymer by TGFTIR-MS analysis. Ind Eng Chem Res. 2012;51:15537-45.

22. Salimi K, Şen SC, Ersan HY, Pişkin E. Fabrication of starch-gpoly(l-lactic acid) biocomposite films: effects of the shear-mixing and reactive-extrusion conditions. $\mathrm{J}$ Appl Polym Sci. 2017;134:44490.

23. Wootthikanokkhan J, Kasemwananimit P, Sombatsompop N, Kositchaiyong A, Ayutthaya SI, Kaabbuathong N. Preparation of modified starch-grafted poly(lactic acid) and a study on compatibilizing efficacy of the copolymers in poly(lactic acid)/thermoplastic starch blends. J Appl Polym Sci. 2012;126:E389-96.

24. Yang X, Jiang Y, Li W, Chen Y, Chen Y. Synthesis and application of esterified starch-g-polylactic acid as drug carriers. Mater Test. 2014;56:331-5.

25. Yu C, Zhou Q, Ciao F, Li Y, Hu H, Wan Y, Li Z, Yang X. Enhancing Doxorubicin delivery toward tumor by hydroxyethyl starch-g-polylactide partner nanocarriers. ACS Appl Mater Interfaces. 2017;9:10481-93.

26. Zhu Z, Zhuo R. Slow release behavior of starch-g-poly(vinyl alcohol) matrix for 2,4,5-trichlorophenoxyacetic acid herbicide. Eur Polym J. 2001;37:1913-9.

27. Sabaa MW, Abdel Magid EH, Mohamed RR. Maize starch-gpoly(n-vinylimidazole) synthesis and its applicationin sewage water treatment. Res Rev J Chem. 2017;6:47-59.

28. El-Hamshary H, Fouda MM, Moydeen M, Al-Deyab SS. Removal of heavy metal using poly ( $N$-vinyl imidazole)-graftedcarboxymethylated starch. Int J Biol Macromol. 2014;66:289-94.

29. El-Hamshary H, Fouda MM, Moydeen M, El-Newehy MH, AlDeyab SS, Abdel-Megeed A. Synthesis and antibacterial of carboxymethyl starch-grafted poly(vinyl imidazole) against some plant pathogens. Int J Biol Macromol. 2014;72:1466-72.

30. Worzakowska M, Torres-Garcia E, Grochowicz M. Kinetics of the oxidative decomposition of potato-starch-g-poly(phenyl methacrylate) copolymers. Polym Degrad Stabil. 2015;120:384-91.

31. Worzakowska M, Torres-Garcia E, Grochowicz M. Degradation kinetics of starch-g-poly(phenyl methacrylate) copolymers. Thermochim Acta. 2015;619:8-15.

32. Worzakowska M. Starch-g-poly(benzyl methacrylate) copolymers. J Therm Anal Calorim. 2016;124:1309-18.
33. Worzakowska M. Thermal behavior, decomposition mechanism and some physicochemical properties of starch-g-poly(benzyl acrylate) copolymers. J Therm Anal Calorim. 2016;126:531-40.

34. Worzakowska M. The effect of starch-g-copolymers structure on the oxidative behavior studied by the TG/DSC/FTIR-coupled method. J Therm Anal Calorim. 2017;129:367-76.

35. Worzakowska M. Starch-g-poly(phenyl acrylate) copolymerssynthesis, characterization and physicochemical properties. Starch Starke. 2017;69:1700027.

36. Worzakowska M, Torres-Garcia E. The effect of the grafting percentage of starch-g-poly(phenyl acrylate) copolymers on their pyrolysis and kinetics studied by the TG/DSC/FTIR/QMS-coupled method. Polym Degrad Stabil. 2017;139:67-75.

37. Worzakowska M. Synthesis and some physico-chemical properties of novel starch-g-poly(citronellyl acrylate) copolymers. Starch Starke. 2018. https://doi.org/10.1002/star.201700330.

38. Worzakowska M. Chemical modification of potato starch by graft copolymerization with citronellyl methacrylate. J Polym Environ. 2018;26:1613-24.

39. Worzakowska M. Thermo-oxidative decomposition mechanism of starch-g-poly(citronellyl methacrylate) and starch-gpoly(citronellyl acrylate) copolymers. J Therm Anal Calorim. 2018;132:543-51.

40. Pagacz J, Hebda E, Janowski B, Pielichowski K. Thermal decomposition studies on polyurethane elastomers reinforced with polyhedral silsesquioxanes by evolved gas analysis. Polym Degrad Stabil. 2018;149:129-42.

41. Wilkie CA. TGA/FTIR: an extremely useful technique for studying polymer degradation. Polym Degrad Stabil. 1999;66:301-6.

42. Materazzi S. Thermogravimetry-infrared spectroscopy (TGFTIR) coupled analysis. Appl Spectrosc Rev. 1997;32:384-404.

43. Yuan JJ, Tu JL, Xu YJ, Qin FGF, Li B, Wang CZ. Thermal stability and products chemical analysis of olive leaf extract after enzymolysis based on TG-FTIR and Py-GC-MS. J Therm Anal Calorim. 2018;132:1729-40.

44. Reggers G, Ruysen M, Carleer R, Mullens J. TG-GC-MS, TGMS and TG-FTIR applications on polymers and waste products. Thermochim Acta. 1997;295:107-17.

45. Cui S, Wei P, Li L. Thermal decomposition behavior of poly(propylene carbonate) in poly(propylene carbonate)/poly(vinyl alcohol) blend. J Therm Anal Calorim. 2018. https://doi. org/10.1007/s10973-018-7297-5.

46. Wang K, Den J, Zhang Y, Wang C. Kinetics and mechanisms of coal oxidation mass gain phenomenon by TG-FTIR and in situ IR analysis. J Therm Anal Calorim. 2018;132:591-8.

47. Bartyzel A, Kaczor AA, Głuchowska H, Pitucha M, Wróbel TM, Matosiuk D. Thermal and spectroscopic studies of 2,3,5-trisubstituted and 1,2,3,5-tetrasubstituted indoles as non-competitive antagonists of GluK1/GluK2 receptors. J Therm Anal Calorim. 2018;133:935-44.

48. Lim ST, Lee JH, Shin DH, Lim HS. Comparison of protein extraction solutions for rice starch isolation and effects of residual protein content on starch pasting properties. Starch Stärke. 1999;51:410-5.

49. Krishnaswamy KG, Sreeenivisan A. Separation and determination of the amylose and amylopectin fractions of starch. J Biol Chem. 1948;176:1253-61.

Publisher's Note Springer Nature remains neutral with regard to jurisdictional claims in published maps and institutional affiliations. 